\title{
7. Diasporic Spaces, Intersectional Homing Desires
}

Besides the family, the diasporic community in Switzerland is another critical site where queer migrant women's national, cultural, and sexual identities are negotiated. As migration scholars have pointed out, the diasporic community not only represents an emblematic locus for homeland nostalgia but especially also a site of resistance against racism in the host country (Espiritu 2003, Holmes 2009). As such it promises to provide a sense of home, security, and solidarity for immigrants. However, this sense of belonging is often denied to, and complicated for, queer migrant women. Their accounts associate mainstream diasporic spaces with estrangement or experiences of exclusion due to sexual dissidence. ${ }^{1}$ At the same time, the diasporic community remains a vital site for queer women to renegotiate Indonesianness, Peruviannes, Bosnianness, and so on. Despite interviewees' often ambivalent relationships to their families and their diasporic community, their homeland culture, their fellow citizens, or other culturally hybrid people represent crucial points of reference and sources of identification for them. In the absence of designated spaces where queer migrant women can share both their migrant experience (and/or their homeland cultural identity) and their sexual identity within the same space-time, home-making often centers around the creation of such 'intersectional' spaces in which they can feel recognized in crucial aspects of their Selves simultaneously.

Chapter 7.1 addresses queer migrant women's experiences of racism and xenophobia in Swiss society, showing how these mechanisms of exclusion coagulate with homophobia to effectuate both exposure and invisibility. Chapter 7.2 is concerned with different ways in which interviewees relate to their diasporic communities in Switzerland. The remaining parts of the chapter engage with how, in the absence of designated queer/diasporic spaces, queer migrant women strive to create spaces in which crucial aspects of their Selves are reconciled. By 'queering' diasporic spaces, by 'diasporizing' lesbian spaces and by attaching 'homing desires' to the bodies of real or imagined partners and friends, sometimes fleeting, sometimes more permanent homes are established in which queer migrant women can be migrant-and-queer(-and-other-things).

Under 'mainstream' diasporic spaces I subsume diasporic spaces that are not explicitly queer and hence inscribed by heterosexual norms. 


\subsection{Negotiating Racism and Xenophobia as an 'Ausländerin' in Switzerland}

Ich bin eine extrem extrovertierte Person im Vergleich zu vielen Leuten, und in Norwegen habe ich nie ein Problem gehabt Leute kennen zu lernen. Und wenn ich hier in die Schweiz gekommen bin habe ich so ein Cefühl gehabt von wirklich eine Fremde zu sein und niemand möchte mich anfassen und niemand sieht mich und niemand möchte mit mir sprechen. Und das hat mir dann extrem schlechten Selbstgefühl oder Selbstwert gegeben. Weil ich konnte es einfach nicht verstehen es war für mich eine total fremde Situation. Und ich habe keine Ahnung, dass man kann sich so alienmässig fühlen, oder? So wie eine kleine Insel.

I am an extremely extroverted person in comparison to many people, and in Norway I never had a problem getting to know people. ${ }^{2}$ And when I came here to Switzerland I had such a feeling of like really being a stranger and nobody would like to touch me and nobody looks at me and nobody would like to talk to me. And this gave me an extremely bad sense of Self or self-esteem. Because I could simply not understand it, it was a completely new situation for me. And I have no idea that one can feel so alienlike, you know? Like a small island.

-Ayesha Umar

Like non-queer immigrants (see Chapter 2.2), the queer migrant women I spoke to are acutely aware of their visibility and vulnerability as perceived 'foreigners' in Switzerland, and like Ayesha Umar often express feelings of social isolation. Being perceived as 'foreign' is generally experienced as a bigger social problem than being a lesbian. As Charlotta Sembiring points out when commenting on her social isolation at her workplace, "before talking about being lesbian I think really we are considered being foreigners." Being a foreigner is experienced as a status that can never be shed, exposed by interviewees' recurring utterances like "I will never be Swiss" - regardless of whether Swiss citizenship has been obtained or not. While not all interviewees have been confronted with blatant racism and xenophobia (the latter I use as a translation for the German term Ausländerfeindlichkeit, literally 'hostility to foreigners'3), there is generally a high level of sensitivity towards subtle exclusions, and these cause a deep sense of insecurity and unbelonging. This awareness also extends to interviewees who do not perceive themselves as targets of anti-immigrant animosities. These interviewees frame themselves as lucky exceptions, which they explain by reference to their individual 'advantages' such as having an atypically light skin (Beatriz Krais), being able

2 Ayesha Umar's family, originating in Pakistan, moved to Scandinavia when she was ten years old. She lived there until she came to Switzerland for the first time in her mid-twenties, see also Chapter 6.1.3.

3 Mutlu Ergün, German author, performer, and researcher, differentiates between racism (Rassismus) and xenophobia (Ausländerfeindlichkeit). He points to the paradox of applying the term Ausländer (and thus also Ausländerfeindlichkeit) to people of color who were born and raised in a Western country and/or hold the passport of this country. In his view hostile acts against people of color therefore clearly need to be conceptualized as racism (https://reclaimsociety.wordpress.c om/2011/06/04/01-06-mutlu-ergun-wo-kommst-du-her\%e2\%80\%9d-\%e2\%80\%93-p-o-c-als-neokolonialer-widerstandsbegriff-in-deutschland/, downloaded on May 10, 2020). 
to rely on a tight network of relatives upon arrival in Switzerland (Jimena Reyes), or being a member of an ethnic group perceived to be less targeted by racism than others (Siti Mohd Amin).

Different strategies are devised to mitigate exposure as an Ausländerin. Self-portrayals often embrace the image of being a 'good immigrant' learning the language and incorporating 'Swiss values,' which, as discussed earlier, also involves becoming a 'good lesbian.' While such strategies of integration and assimilation serve to establish a sense of ontological security and a 'normal' life within Swiss mainstream society, they also effectively invisibilize cultural difference. At the same time, as Laura Georg, daughter of a Sri Lankan father and a Swiss mother born and raised in Switzerland, points out, the success of such strategies will always remain partial:

TB: Was meinst du mit die Sprache rettet dich?

LG: Die Sprache [Schweizerdeutsch] rettet mich vor dem Auffallen. Und vor dem mich selber auch positionieren müssen vor anderen. Also ich glaube ich würde es wirklich vergleichen-so das Leben das du als Lesbe hast ist jeden Tag musst du dann so überlegen: Ja, soll ich es sagen oder nicht sagen? Ist es da wichtig oder ist es irrelevant? Und bei der Dunkelhäutigkeit ist es auch ein bisschen so, obwohl man die Dunkelhäutigkeit ja noch eher sieht, aber [...] viele sind eben doch zufrieden wenn ich [auf Schweizerdeutsch] sage: 'Ich bin Schweizerin.' Dann passt das, oder? [...] Aber einfach man kann beliebig immer wieder darauf zurückgeholt werden: 'Woher bist du?' Und: 'Bist du eine Lesbe oder bist du heti' oder wie auch immer. Einfach die Abweichung die-man ist nie sicher, oder? Man kann sich nie hinein blenden so ganz.

TB: What do you mean the language saves you?

LC: The language [Swiss German] saves me from standing out. And also from having to position myself in front of others. Actually, I think I would really compare it- like the life you have as a lesbian is every day you have to like deliberate: Well, should I tell or not tell? Is it important here or is it irrelevant? And with having brown skin it's a bit like that as well, although this tends to be more visible, but [...] still many are satisfied when I say [in Swiss German]: 'I'm Swiss.' Then everything is okay, eh? [...] But it's just like you can be thrown back to it randomly again and again: 'Where are you from?' And: 'Are you a lesbian or are you hetero' or whatever. Just the deviance which-you're never safe, you know? You can never blend in entirely.

- Laura Georg ${ }^{4}$

Laura Georg addresses her vulnerability as a multiply deviant subject, and especially the (lack of) control she has over the 'visibility' of her differences. 'Visibility' in this context means an involuntary exposure and bringing up of one's perceived difference as inflicted from the outside. Personal strategies are pondered by which control can be regained in such instances of exposure. Especially native Swiss German is identified as a powerful instrument to minimize the visibility of having a brown skin. At the same time, having

4 Laura Georg works with language professionally, and although here she refers to everyday interactions rather than her professional writing, from her narrative it transpires that her choice of profession stood in connection to her relationship to language as described here. 
a brown skin is considered "more visible" than sexual orientation, the exposure of which can be held at bay - to a certain extent - by 'not telling.'

Laura Georg expresses this statement in the context of her insight that there are no other women "who look different" in the Swiss lesbian community:

Es gibt [in der Lesbenszene] tatsächlich keine-also keine Frauen, die anders aussehen. Also wie wenn etwas das man anders hat, nämlich das Land oder eben die kulturelle Zugehörigkeit, schon genug ist wo man sich damit befassen muss. Dann kann man sich nicht noch den Stress antun zum nochmals müssen etwas dazu nehmen.

There are really no- well no women who look different [in the Swiss lesbian community]. Like as if something is different about you, namely the country or the cultural belonging, is already enough to deal with. Then you can't additionally burden yourself with the stress of taking on another thing.

- Laura Ceorg

In Laura Georg's eyes it is only her command of Swiss German and her half-Swiss heritage that enable her to "take on" being different 'even' within the lesbian community.

Laura Georg's perspective problematizes the negotiation of multiple displacements based on race/ethnicity and sexuality respectively. She draws a parallel with, yet differentiates between, the visibility of her brown skin and her sexual deviance. In the everyday reproduction of Otherness, both axes of social differentiation incessantly coerce this subject, marked as deviant, into 'coming out' and declaring herself, thus again confirming her positionality as a (doubly) deviant subject. In the case of the migrant identity, this crystallizes in the ever present if not always voiced questions "Where are you from?" or "Where are you really from?" respectively. As Barbara Wiegand points out, "ich kommuniziere meine Gemischtrassigkeit nicht, die wird mir kommuniziert." - "I don't communicate my mixed race, it gets communicated to me."

Still, as Laura Georg's statement testifies to, the visibility of both the migrant and queer positionality is not straightforward or objective but situational and dependent on the vision of the interlocutor and the space in which the interaction takes place. The exposure of deviance can be influenced to a certain degree by using strategies like the instrumentalization of language or the choice (not) to communicate sexual orientation. However, as both Laura Georg and Barbara Wiegand point out, the visibility of both the migrant and the queer positionality can never entirely be controlled. Native language skills may minimize the visibility of skin color; and homosexuality may be made more or less apparent by the choice of clothing, hairstyle, or body language, but as another interviewee noted, "even if I wanted to I could not completely hide my being a lesbian- my visibility as a lesbian is not something I can shed for the occasion just like that." Being used to wearing sport clothes and short hair, and having formed the habit of speaking with a rather low voice, sometimes using a rough sort of vocabulary, and moving in a rather masculine manner render it impossible for her, she says, to just switch to main- 
stream femininity (including "lipstick, high heels, or even only a skirt") in a "credible manner."

Such a perspective works against two persistent assumptions in popular discourse: that non-white skin color is objectively visible to everybody, rendering people of color unproblematically identifiable as such; and that, by contrast, homosexuality can be hidden ad libitum. ${ }^{6}$ Laura Georg's statement discounts such views and reframes different forms of feeling both visible and invisible as continua contingent on the specific positionality and performance of a particular subject. The in/visibility of social markers vary. Whether one is visible as a 'foreigner' because of a name, an accent, a phenotype, communicative behavior, clothes, food, religious rituals, or other markers makes a difference since each of these markers (dis)allow different kinds of 'passing.' Laura Georg is "saved" from "standing out" to a certain extent by means of her accent-free Swiss German. Nermina Petar uses the name 'Nora' as her pseudonym on lesbian chat sites in order to erase her Bosnian background; Nora is hence also the name by which she is known in the lesbian community, which she describes as "her circles." Confirming Laura Georg's thesis that for intersectionally positioned subjects it can often be too much to take on multiple fights, Nermina Petar contends that "wenn du Ausländer bist, und nebst dem dass du lesbisch bist, dass du noch damit zu kämpfen hast, dass du Ausländerin bist, hört man-merkst es am Namen und du wirst zum Teil ausgegrenzt" - "if you are a foreigner, and apart from being lesbian you additionally have to fight with being a foreigner, one hearsnotices it from the name, and you are sometimes excluded." The argument here is not that queer migrant women always seek to hide their racial or ethnic difference - they do not - but to highlight their efforts to gain control over their exposure to multiple discriminations. Laura Georg's point in her account about being saved by Swiss German is that it remains beyond her control when and where she is confronted with one or the other of her Otherness; "you can be thrown back to it randomly again and again."7

As Barbara Wiegand points out, such multiple displacements intertwine ("sich verschränken"), coagulate ("koagulieren") and ball ("sich zusammenballen"), which renders it

These quotes are based on verbatim notes taken during an explorative interview which was not audio-recorded.

6 Until a few years ago Swiss asylum practice, too, worked from the assumption that homosexuality can be hidden. This resulted in queer asylum seekers being sent back to their home countries based on the argument that they will not encounter any problems as homosexuals if they live their homosexuality in secret. This logic often persists at least implicitly in Western European asylum systems, even though a European court verdict explicitly ruled such argumentation invalid in 2014. Paradoxically, throughout Europe asylum seekers are at the same time subject to processes aimed at (dis) proving their homosexuality, which are grounded in a visual economy implying that homosexuality is visible (e.g. men 'looking too masculine to be gay,' or 'acting too girlish to be credible as gay,' see Chapters 2.3.2 and 8).

7 The involuntary visibilities Laura Georg addresses here need to be delimited from the visibility of queer migrant subjects this study seeks to establish. While these involuntary visibilities are in fact less visibilities than repetitive acts of social boundary making and stereotyping that eventually erase rather than make visible queer migrant subjects and their realities, the aim of this study is to engage with, and hence make visible, these very realities shaped by processes of racialization. Still, ethical questions as to whether this intended kind of visibilization is possible at all, and/or useful and morally valid in the way attempted here, are of course justified and invited. 
impossible for her to discern what exactly triggered a hostile act. In a rare window of opportunity, Barbara Wiegand entangles the "Dorftrottel" (village idiot) of her village in a conversation, based on the assumption that he might verbalize the subliminal thoughts other villagers only think to themselves or would never confront her with directly. $\mathrm{He}$ does:

Ich versuche herauszufinden wo er mich festnagelt, weil er hat drei Kategorien gehabt, 'Frauen,' er ist ein Frauenhasser, dann hat er die Kategorie gehabt 'links.' Und das sind alle die, die Bücher lesen, oder? Und dann hat er noch die Kategorie 'Ausländer' gehabt. Und er hat immer 'ihr' gesagt, dann hat er so getan das sind sicher die Frauen [...].

I try to figure out where he puts me [literally 'where he nails me down'], because he had three categories, 'women,' he is a woman-hater, then he had the category 'left-wing.' And that's all those that read books, eh? And then he had the category 'Ausländer.' And he always said 'you' [plural] then he acted as if for sure it was the women [in the sense that, at the end of the day, it was the women that were the (biggest) problem] [...].

-Barbara Wiegand

This is not to say that it all boils down to gender, or in fact to any singular social marker, but to point to queer migrant women's desire to identify what exactly triggered an animosity. While some hostilities are quite easily classifiable as either racist or homophobic, other incidents leave a nagging uncertainty as to what it was that caused the negative reaction. Note that sexuality does not emerge as a category in Barbara Wiegand's above negotiation; in her village she lives "very much in the closet," which is why in this specific interaction sexuality can only work on a subliminal level.

Hence, although rarely confronted with blatant racism, queer migrant women are subjected to multiple mechanisms of exclusion that not only target them as 'foreigners' but also as queers and as women. Devising strategies to mitigate this exposure, they find that the in/visibilities of their deviances ultimately remain beyond their control. 'Blending in' by assimilation can always only be achieved to a certain extent and is problematic as it requires the denial of at least part of one's cultural identity. However, as will be discussed next, queer migrant women often seek to renegotiate and reappropriate rather than negate or erase this cultural identity. Especially interviewees who were born in Switzerland thereby often seek to become recognized both as a 'real' Swiss and as a 'Sri Lankan' (for instance) at the same time. While the impossibility of allocating specific instances of discrimination to one form of Otherness or the other - sexuality, gender, or race - creates a deep sense of insecurity, overall, in everyday life, interviewees tend to feel more exposed to discrimination as 'foreigners' than as queers or as women.

\subsection{Ambivalent Diasporic Spaces}

This sub-chapter is concerned with the relationships the women I interviewed entertained with their diasporic communities, and with the role diasporic spaces played in their everyday negotiations of 'home.' Like family relations, connections to diasporic 
communities were diverse, complex, and marked by ambivalent feelings. No account conveyed a sense of deep immersion in a diasporic community, and unlike many heterosexual migrant women in Switzerland (Riaño 2003a), women who were active in their community and attended events organized by and for fellow countrypeople on a regular basis remained the exception. However, while many interviewees were relatively disengaged from their diasporic community, ties to the community were still never completely severed. ${ }^{8}$ Within these limits, relationships to diasporic communities took a variety of forms that will be discussed in the following.

This sub-chapter distinguishes four intersecting ways of relating to diasporic communities that were discernible in interviewees' accounts, taking into consideration these different kinds of connectivities overlapped and changed in the course of biographies. The first way of relating to the diasporic community is represented by those interviewees who took a decidedly anti-identitarian stance with regard to their social network, refusing to organize or understand their networks along the lines of this or that minoritarian identity. Second, some felt they did not have much in common with other members of their diasporic community due to the perceived dominant heteronormativity in these circles. Consequently, these interviewees were not able to create a deep sense of belonging within its folds. Third, some associated their diasporic community with homophobia or a forbidding silence around same-sex sexuality and accordingly distanced themselves from these circles. And fourth, there were those who strove for full participation in their diasporic communities.

'Diasporic community' in this chapter specifically refers to what interviewees perceive as a 'mainstream' diasporic context (e.g. "bosnische Kreise" - "Bosnian circles"). These communities for instance manifest themselves in the form of community centers or migrant organizations addressing specific nationalities (e.g. 'Bosnian') or regions of origin (e.g. 'Galician' or 'Asian'). These institutions organize events on the occasion of holidays or other happenings in the home country, in addition to regular gatherings and events ("spanische Festli"- "Spanish parties").

\subsection{1 "I don't need it every weekend": Resisting Relegation to Minoritarian Spaces}

Interviewees who take a decidedly anti-identitarian stance with respect to their social network emphasize that their circle of friends includes "Tout le monde!" (Beatriz Krais, Jimena Reyes) rather than mainly lesbians or compatriots, for instance. To Jimena Reyes it is important "[de] ne pas rester sur des réseaux ou des ghettos ou des choses comme ça, moi j'aime tout le monde, les Noirs, les Chinoises, les hétérosexuels, les transsexuels, enfin j'aime tout le monde, et j'ai pas du tout envie de me sentir uniquement dans un certain lieu" - "not to stay confined to specific networks or ghettos or things like that, I like everyone, the Black, the Chinese, the heterosexuals, the transsexuals, in the end I like everyone, and I really

8 An exception was the couple Nara Agayeva and Ramiza Salakhova, see below. The couple separated themselves from countrypeople because they had experienced their homeland society as deeply homophobic. Additionally, they feared that contact to countrypeople may allow Ramiza Salakhova's abusive husband, who still lived in their home country, to find his wife in Switzerland. 
don't feel like thinking of myself as belonging to one specific place only." She and others feel especially alienated by what they term "lesbian ghettos" and by certain circles of their compatriots "qui sont restée trop entre eux" - "who have stayed too much among themselves," without making any efforts to connect to other people in Switzerland or to "integrate" (Beatriz Krais). This does not mean that these participants never visit lesbian and diasporic spaces - they do. Nevertheless, they do not represent a central site of identification for them.

While these interviewees typically welcome meeting up with compatriots once a year or so to celebrate an election, speak their mother tongue, or enjoy their favorite childhood foods, they would likely agree with Beatriz Krais' qualification that "y a pas besoin que ce soit tous le week-ends ça quoi" - "I don't need it every weekend." Although they know a lot of compatriots, "je ne vis pas beaucoup avec eux" - "I don't experience much with them," as Jimena Reyes states. There are not many compatriots who are close friends, yet nor are there many lesbians, although meeting lesbian friends remains meaningful because, as Beatriz Krais formulates, "ça fait du bien de voir des gens qui vivent la même chose que nous" - "it feels good to see people that experience the same thing we do."

Ariane Velusat's reflections on her relationship with other Venezuelans in Switzerland crystallizes this anti-identitarian perspective (I was asking her at the end of the interview whether there was anything she had wanted to say and I had not asked):

Y a une question que j'ai pensé que vous allez poser, c'était si je faisais partie d'un groupe de personnes de mon pays, du Venezuela ou comme ça, et puis je m'étais dit que, non, que c'était pas le fait d'être avec des personnes du Venezuela qui me faisait sentir plus dans mon pays. Que, non, que c'est plus des valeurs ou des idées, ou des manières d'être ou des manières de vivre, que je peux partager avec d'autres personnes. Mais que c'est pas parce qu'une personne vient du Venezuela, que je vais sentir forcément l'envie d'être amie de cette personne, pour me sentir plus proche de chez moi. Non. Voilà. Si. Parce que je sais que souvent, oui souvent y a ce cette idéelà. Que si je connais un cercle d'amis du Venezuela [...] je vais ressentir le besoin de devenir ami. [...] Et j'ai connu pas mal de Vénézuéliens mais, non.

There was a question I thought you would ask, it was whether I was part of a group of people from my country, from Venezuela or something, and then I told myself that, no, that it was not being with Venezuelan people that made me feel more in my country. That, no, it's rather values or ideas, or ways of being, of living, that I can share with other people. But that it's not necessarily because a person comes from Venezuela that I will feel like being friends with this person, in order to feel closer to home. No. Voilà. Yes. Because I know that often there is this idea. That if I know a circle of friends from Venezuela [...] I will feel the urge to become friends. And l've known quite a few Venezuelans but, no.

-Ariane Velusat

Ariane Velusat works towards feeling "more in my country," that is, at home, in Switzerland; but she finds herself incapable of forging a sense of connectivity over a shared nationality alone. For her, friendship needs to be based on shared values and ways of living. As she details later in the interview, these shared values are sometimes also grounded in homeland culture. But her connecting points are more differentiated and diverse and 
include specific positions and approaches to homeland values (such as conservative versus liberal stances on political issues); cultural hybridity emerging from the diasporic experience; being sexually non-conforming; and sharing leisure activities like dancing or cooking together.

Such anti-identitarian stances occur in accounts by interviewees both from the first and the second 'generation.' Narratives of interviewees from the 'second generation' or of interviewees who came to Switzerland as children tend to construct the anti-identitarian perspective as 'natural,' invoking their diverse social network that has grown organically in Switzerland over the years at school, at work, in sports clubs, in their neighborhoods, and so on. By contrast, in the case of 'first generation' immigrants the anti-identitarian stance appears as an attitude that is consciously claimed. Closely reading Ariane Velusat's statement, I also interpret the anti-identitarian stance as an act of resistance in the face of dominant discourses relegating Others to 'other' spaces. This is implicit in Ariane Velusat's expectation that in the research interview she would be confronted with the assumption that Venezuelans want to be with other Venezuelans. Conversely, on other occasions that I did explicitly ask about social ties to the diasporic or the lesbian community, these questions were occasionally met with irritation, which I read as an expression of interviewees' interpretation that I was assuming a natural connectivity among national or ethnic groups or among sexually non-conforming groups.

\subsection{2 "It's not my scene": A Sense of Difference and Unbelonging}

The second way of relating to diasporic communities is marked by estrangement and a lack of a sense of belonging. These interviewees do not feel connected to their diasporic community because they feel they do not share interest in the topics discussed and negotiated within mainstream diasporic circles. Augusta Wakari feels at a loss as to how to "bring myself in" to Indonesian groups, which she perceives to be dominated by Indonesian women married to Swiss men:

I don't really be in that kind of circle. I don't know what to say 'Hm? Really? Äng ong ang ang' (acts as if she is struggling for words, laughs). Really. Most are their husband. 'Ah my husband.' (Exasperated) Oh it's typical women! Typical women! 'Oh, my husband is this, oh my husband is that,' I say, 'Okay: No, it's not my scene actually. It's not my scene.'

-Augusta Wakari

The perceived dominant heteronormativity in diasporic circles, moreover dominated by women compatriots speaking about their Swiss husbands, establishes too great a distance to Augusta Wakari's own experiences to allow for a sense of connection. This sense of exclusion experienced based on female compatriots' 'straightness' is sometimes also tied to issues beyond gender and sexuality: "For sure this [=the Malaysian diasporic community in Switzerland] is more straight, with religion (and) everything," Siti Mohd Amin states. Despite this perceived straightness and religious conservatism, she sometimes joins Malaysian events since they represent some of the very sparse points of social contact in her everyday life: "I don't care. Just go, and wallawallawalla [=blahblah- 
blah], and I go home." For those who have partners, additional issues emerge regarding the heteronormativity inscribed in mainstream diasporic spaces: Ariane Velusat and her partner have stopped going to the "boites latinos" (Latino clubs) they used to go to after they had first met "parce que on n'a pas écrit ici 'On est ensemble' (pointe sur son front) donc les hommes ils viennent draguer ils sont collants comme d'habitude quoi" - "because we don't have written 'We are together' here (indicates her forehead) so the men they come on to you, they stick to you as usual."

Heteronormativity and attendant gender performances, normative biographies, conservative perspectives on religion, and issues of class coagulate to effectuate a sense of disconnection from mainstream diasporic circles. As discussed in Chapter 6, not being married and/or not having children is thereby seen as a particularly insurmountable difference in the life experience of oneself and female compatriots. As childless queers, interviewees do not feel they have many "common issues" with female compatriots - or indeed any women - who have married (possibly at a young age), have children, and chiefly act as housewives and mothers.

\subsubsection{Negotiating Homophobia in the Diasporic Community}

The perceived conservatism and heteronormativity of mainstream diasporic circles sometimes took the shape of a more critical perspective on these spaces as explicitly homophobic, which represents the third way of relating to diasporic communities that emerged from the interviews. Some interviewees avoid community events explicitly on grounds of the homophobia and/or profound and forbidding silence around samesex sexuality they have experienced in these spaces. The social worlds of these interviewees tend to be particularly segregated. Nour Saber says that when she still lived in France, her circle of friends was "essentiellement des femmes européennes, [...] mais jamais des femmes arabes ou bien des femmes musulmanes" - "mainly European women, [...] never Arab women or Muslim women." She did not tell the few Arab friends she did have that she was a lesbian "parce que c'est un sujet tabou, parce qu'aussi c'est un sujet qui fâche. C'est un sujet les gens vous disent 'Non, c'est une maladie" - "because it's a taboo, because it's also a subject that irritates people. It's a subject [to which] people tell you 'No, it's a disease." Based on this experience Nour Saber continues to keep the subject silenced among compatriots and other Arabs in Switzerland, a compartmentalizing strategy that was mirrored in many other biographies. Nour Saber began to segregate her coming-out strategies and her social life along the lines of ethnicity/religion after losing her best (Arab) friend upon telling her about her sexual orientation. The woman, who like Nour Saber lived in France, never answered any of her queries again. In Nour Saber's view this incident was not an individual occurrence, but a reaction rooted in the homophobia in Arab societies that is transported to Europe through migration:

Parce que même un étudiant [arabe], qui fait un troisième cycle [en France] et tout aussi vraiment, ils ont du mal à comprendre ça, ils étaient tellement, farinés, dans cette société, et puis dans les préjugés de la société d'origine, ils sont tellement imprégnés de la société d'origine qu'après ils arrivent plus à enlever tous ces schémas sociaux de leur tête. Donc le préjugé il est toujours là, même s'ils sont à l'étranger. 
Because even a[n Arab] student, who is at university [in France] and everything, they really also have a hard time understanding this, they were so, immersed, in this society, and then in these prejudices of the society of origin, they are so impregnated by the society of origin that after this they can't manage to get rid of all these social schemes in their heads. So the prejudice is always there, even if they are abroad.

-Nour Saber

Nour Saber locates the origin of the homophobia she detects among Arab students in Paris in the "social schemes" they were "immersed in" when growing up in their countries of origin, which they carry with them to France, where they are conserved "in their heads." These values and attitudes are depicted as being so pervasive and affective that it is not possible for migrants to "get rid" of them after migrating. Homophobia hence appears as something fixed and unchanging that is situated in the "society" of Arab countries and inscribed in the bodies of migrants from these countries.

The formulation that "even a student at university" (emphasis added) is unable to discard these deep-seated resentments against sexually non-normative people is related to Nour Saber's view that in the Arab-Muslim world, the occurrence of homosexual identification per se and the realization of 'sexual migrations' (that is, migration projects that are directly motivated by the wish to lead a homosexual life in Europe) are highly contingent on social status, educational level, and religiosity. Nour Saber accordingly frames homosexuality and sexual migration as "un phénomène élitiste" - "an elitist phenomenon" - reserved for members of the elevated classes:

C'est pas quelqu'un qui appartient à un milieu social modeste, qui va se dire 'Ok, moij'ai envie de vivre mon homosexualité à l'étranger donc je vais émigrer.' Pourquoi il peut pas? Pour deux raisons. La première c'est que, il a pas les moyens intellectuels de lutter contre la société. Donc, il va se plier aux besoins de la société, et puis aux normes de la société. Et puis pour lui il va vraiment, il va pas s'écouter, il va se dire 'Ok. Même si moi, j'ai envie, et je sais que je suis homosexuel, mais je peux rien faire.' C'est-à-dire, intellectuellement c'est des gens qui ont pas les moyens de lutter et de tenir tête, à la société. Ça c'est une chose. La deuxième chose c'est une raison financière. Parce que, lorsque on arrive ici [en Europe], il faut beaucoup de moyens financiers [...] C'est pour ça qu'on considère que l'homosexualité est un phénomène élitiste, c'est-à-dire un phénomène de classe social, dans le monde arabo-musulman. Une femme d'une classe populaire, d'une classe modeste, elle va se marier et puis elle va avoir des enfants, et puis elle va rester toute leur vie comme ça, malheureuse, parce que elle a ni les moyens d'éviter, et puis de faire son choix et de trancher et puis de vivre son homosexualité, de vouloir la vivre elle a pas la force ni social ni intellectuelle et puis elle a pas les moyens.

It's not like someone who belongs to a humble social milieu will tell himself 'Ok, I feel like living my homosexuality abroad, so I will emigrate.' Why can he not do it? For two reasons. The first is that he does not have the intellectual means to fight against society. So he will fold to the needs of society, and the norms of society. And then for him he will really, he will not listen to himself, he will tell himself 'Ok, even if I feel this desire, and know that I'm homosexual, I cannot do anything.' That means that intellectually these are people that don't have the means to fight, to resist society. That's one 
thing. The other thing is a financial reason. Because when you arrive here [in Europe], you need a lot of financial means. [...] This is why homosexuality is considered an elitist phenomenon, that is, a phenomenon of social class, in the Arab-Muslim world. A woman of the working class, of a humble class, will marry and then she will have children, and then she will stay all her life like that, unhappy, because she has neither the means to avoid [that] nor [the chance] to make her choice and make a cut and then live out her homosexuality, she has neither the social nor the intellectual force to want to live it out, and then she also does not have the means.

-Nour Saber

Nour Saber's argument identifies two kinds of positionalities for sexually non-conforming people in Arab societies: The first is inhabited by people from the societal elite, who have the possibility to assume a homosexual identity and migrate to Europe in order to live a homosexual life or assume a homosexual identity in the diaspora. The second positionality is inhabited by people from the "humble" classes, who neither have the "intellectual force" to identify as homosexuals nor the financial means to migrate. Succumbing to social pressures they enter heterosexual marriages and live their same-sex desires in secret, if at all.

Such narratives reiterate homonationalist discourses juxtaposing a homophobic Orient or South against a gay-friendly West. As discussed in Chapters 3.4 and 6.1, not only does such a stance ignore the authorship of the colonizers and their successors in the construction of modern homophobias in the Orient or South, but it also erases the fact that the current trend to outsource homophobias to racialized and ethnicized Others importantly originates in global inequalities and imperialist moves that work towards legitimizing wars and excluding migrant people. In other words, to conclude from Nour Saber's and similar accounts - and from the incisive, very real, and painful experiences of exclusion, discrimination, and pathologization they often speak of - that non-Western societies and their diasporic communities are inherently dismissive of queer sexualities would mean to overlook the deeper and global layers of the structuration of modern homophobias.

Nour Saber's contentions converse with Joseph Massad's critique of the figure of the "Gay International" as discussed in Chapter 3.4 (Massad 2002, 2007, and 2009). Massad "charts the way through which social Darwinism, culturalism, civilizational thinking, Orientalism, western colonial medicine, and colonial law influenced Arab intellectuals since the nineteenth century on how they should think through sexual matters and their centrality to what Europe insisted were civilizational questions." This thinking "institutionalized [sexuality] as a major axis through which society can be normalized (as heterosexual), which in turn necessitated a deviant other (the homosexual)." Massad says that today it is international U.S. and Europe-based LGBT organizations that "incite discourse on sexuality in Arab countries [or in Latin America, India, or Iran etc., as he generalizes elsewhere] and claim that they are trying to push these societies to protect the rights of their homosexual populations, which these international organizations themselves are creating" in their own image (Massad 2009). Massad reiterates Nour Saber's argument that in the Arab world homosexuality is an elitist phenomenon; as he states, "there is a small number of upper class and upper middle class western- 
ized Arabs who are seduced by gayness and the American example of it." The notion of seduction exposes Massad's conceptualization of this phenomenon as a result of Western cultural imperialism as promoted by what he terms the "Gay International," who simultaneously outsources homophobia to the non-Western Other. In contrast to Nour Saber's dichotomization of 'homosexuals' - people from the Arab elite identifying as gays or lesbians - versus 'oppressed' people - people form the "humble classes" who desire their own sex but remain unable to think and/or live it as an identity - Massad contends that the few self-identifying gays and lesbians in the Arab world "are not representative of, nor can speak for the majority of men and women who engage in same sex practices and do not identify themselves in accordance with these practices" (Massad 2009). As mentioned earlier, in Massad's view the "Gay International" is "destroying social and sexual configurations of desire in the interest of reproducing a world in its own image, one wherein its sexual categories and desires are safe from being questioned" (Massad 2007:189). While I consider questionable Massad's move to reduce the sexualities of Arab people identifying as homosexuals to their having fallen for Western ideas about sexuality (see also Makarem 2009), his analysis usefully contextualizes and complicates Nour Saber's argument, and once more points to the many ways in which "stories-so-far" about sexualities intermesh globally.

Nour Saber's view that homophobia among Arabs in the European diaspora originates in the "social schemes" adopted in their home countries is not shared by all interviewees who experienced their diasporic communities as homophobic. A counterexample is Nermina Petar's account. Rather than in the homeland, Nermina Petar locates her parents' and other compatriots' homophobia in the diaspora itself. Nermina Petar shares Nour Saber's strategy of keeping her sexual orientation under wraps in the company of compatriots, and equally segregates her social worlds along the lines of her national and sexual identities. Having been socialized in "Bosnian circles" since she came to Switzerland at the age of ten, recently she has distanced herself from this community. As discussed earlier (Chapter 5), this rupture was based on what Nermina Petar experienced as exceedingly confining heteronormative gender roles and an associated pressure to follow the Bosnian diasporic heteronormative prescript (marry early, have children, and stay within the Bosnian community). While also perceived as omnipresent in the broader Bosnian diasporic community, this prescript was chiefly propagated by her parents. Nermina Petar suspects that the fixation of immigrant parents on "passing on" conservative heteronormative homeland values to their children effectuates even greater pressure on sexually non-conforming children who grow up in the diaspora than on queers who grow up in the home country. Nermina Petar thus attributes to the Bosnian circles in Switzerland an aggravated conservatism compared to Bosnian society in Bosnia and Herzegovina. She postulates that it may in fact be easier to live as a lesbian in Bosnia and Herzegovina than as a Bosnian lesbian in Switzerland:

Das ist wirklich so, dass die, die ausgewandert sind, meine Eltern inklusive, dass sie [...] die Werte wirklich-auf das fixiert sind. Das weiterzugeben. Und wenn ich jetzt meine Tante [in Bosnien] erlebe- [...], die sind viel lockerer. [...] Also ich denke der Druck auf die Bosnier selber ist hier extremer. [...] Vielleicht wäre sogar also lockerer, also einfacher dort unten lesbisch zu 
sein, ich weiss es nicht (lacht). Das bezweifle ich zwar, aber vielleicht würde die Familie anders daraufreagieren, weil sie nicht so auf die Kinder fixiert sind, oder?

It's really like that, that those who have emigrated, including my parents, that they [...] the values really- that they are fixated on this. To pass this on. And if I see my aunt [in Bosnia and Herzegovina] [...], they are much more relaxed. [...] I think the pressure on Bosnians themselves is much greater here. [...] Maybe it would even be more relaxed, I mean easier to be a lesbian down there, I don't know (laughs). I doubt it, but maybe the family would react differently because they are not so fixated on the children, you know?

-Nermina Petar

This statement addresses the pressures theorists like Yen le Espiritu or Gayatri Gopinath diagnose diasporic communities to be exposed to (Espiritu 2003, Gopinath 2005, see Chapters 3 and 6): On the one hand, certain migrant communities (Gopinath discusses South Asian diasporic communities in the U.S.) can come under moral pressure from heteropatriarchal homeland nationalisms depicting diasporic female citizens as inferior, inauthentic, and tainted in comparison to the 'real,' pure national woman 'at home' (Gopinath 2005). In answer, these diasporic communities attempt to position themselves in a positive light vis-à-vis the homeland. As Nermina Petar's statement suggests, this counter discourse is driven by masculinist discourses inscribing alleged national values on the body of the diasporic child, and more particularly the diasporic girl/daughter, who in this way becomes emblem and heeder of national/homeland morale and culture. As Nermina Petar's statement testifies to, this puts diasporic daughters under increased control and pressure.

On the other hand, Espiritu identifies racism in mainstream society as a further crucial force in building moral pressure against diasporic girls/daughters. Espiritu argues that in the face of negative stereotyping and marginalization, migrant communities work towards representing themselves as morally superior to the Western host culture. Once more this dynamic is productive of a discourse of 'our' (e.g. Bosnian) girls/daughters as pure and chaste, who now become pitted against 'Swiss' or 'Western' girls/daughters, who are represented as amoral and sexually corrupt. This perspective is reflected in Nermina Petar's following statement: "Die Bosnier selber meinen, dass die Schweizer selber eher Drogen nehmen, die Mädchen mit dreizehn schon mit Buben ins Bett gehen etcetera, eigentlich eine Art Negativ, wie die Schweizer selber von den Ausländern" - "The Bosnians themselves think that the Swiss themselves tend to take drugs, that the girls sleep with boys at the age of thirteen already etcetera, in fact kind of a negative of what the Swiss themselves think about foreigners." Nermina Petar says that in her childhood, Bosnian children in Switzerland tended to be confined to Bosnian circles in order to separate them as much as possible from Swiss children, with a focus on keeping Bosnian girls away from Swiss boys. Within this logic the figure of the virtuous Bosnian girl is constructed as the morally superior counterpart to the drug abusing and sex-obsessed Swiss girl. As Espiritu points out in the context of her similar findings in the Filipino/U.S. context, "this juxtaposition underscores the fact that femininity is a relational category, one that is co-constructed with other racial and cultural categories." Only that in this instance it 
is the 'margins' (in the case of Nermina Petar: the Bosnian diasporic community) that imagine and construct the 'mainstream' (here: Swiss mainstream society) rather than vice versa (Espiritu 2003:158). Such masculinist evocations of the homeland must hence also be read as forms of resistance against racism and exclusion. This function of the diasporic community as a bulwark against discrimination in the host country further contributes to the complexity of the relationships interviewees entertained to their diasporic communities: Despite their often ambivalent experiences in these spaces, these are not ties that can be severed lightly. These diasporic contestations of national cultures and values are moreover highly sexualized. Within their heteronormative logic, non-heterosexual migrant women are perceived as 'Westernized' by their conservative families or compatriots in the diaspora. Since homosexuality, like the lack of chastity in women, is intrinsically attached to the figure of the sexually immoral Western woman, queer migrant subjects are paradoxically catapulted out of their homeland cultural identity.

The homophobic reactions or silence around homosexuality many interviewees have experienced in certain conservative circles of their diasporic communities hence always also need to be read against the backdrop of heteropatriarchal homeland nationalisms on the one hand and exposure to racist ascriptions in Switzerland on the other. At the same time, trending dominant discourses framing diasporic communities in Switzerland as homophobic form part of a larger narrative attributing gay-friendliness to the West and homophobia to the global Orient or South. The pervasiveness of this narrative is exposed in Nara Agayeva and Ramiza Salakhova's account: In contrast to Nour Saber and Nermina Petar, who have themselves experienced exclusion on the basis of their dissident sexuality within their diasporic communities, the couple avoids not only their own diasporic community but other immigrants in general because they imagine them to be homophobic (see Chapter 8).

As mentioned above, disidentification with the diasporic community may lead to a segregation of social worlds, which includes a segregation of different aspects of the Self. Nermina Petar emphasizes the work involved in moving from one space and social positionality to another:

Manchmal bin ich wie ein Chamäleon. Wenn ich bei den Bosniern dabei bin, was eigentlich selten ist aber ab und zu passiert es, dann passe ich mich ihnen an. Sei das an der Kleidung, also nichts extrem Weites. Normal so wie jetzt aber so gewisse T-Shirts gehen ein bisschen weiter runter, odersei es [...] über das Thema reden oder einfach das Lesbischsein ja nicht erwähnen, ich weiss mit denen kann ich nicht darüber diskutieren und will ich gar nicht. [...] ] ]a in dem Kreis bin ich halt die Nermina, die Tochter von einem [...] wohlhabenden, religiösen Mann. Und in dem anderen Kreis, der eigentlich mein Kreis ist bin ich die Nora [Nerminas Kosename], [dort] kann ich so sein wie ich bin. Weil sie akzeptieren mich so.

Sometimes I'm like a chameleon. When I join the Bosnians, which is rare but sometimes it happens, then I adapt to them. Be this with respect to clothing, well nothing extremely loose. Normal like now but certain T-shirts reach a bit further down, or be it [...] talking about the issue you know, just under no circumstances mentioning being a lesbian, I know I can't discuss that with them and I don't want to. [...] Yes, it's a fact 
that in these circles I'm Nermina's, the daughter of a [...] rich, religious man. And in the other circle, which is actually my circle, I'm Nora [Nermina's nickname], [there] I can be the way I am. Because they accept me like that.

-Nermina Petar

Here the negotiation of homosexuality in the diasporic community coagulates with a host of other areas of conflict. There are cross-cultural negotiations of gender and particularly female chastity, manifested in Nermina Petar's strategy of wearing a slightly longer T-shirt; and there are issues of respect between parent and child. Taken together, these conflicts generate complex and ambivalent loyalties on the part of Nermina Petar. She contrasts this ambivalent diasporic space with the sense of acceptance she experiences in "my circle," which mainly consists of Western European women, many of whom are lesbian.

Comparing spaces is a typical practice in accounts describing the segregation of lifeworlds along multiple lines of social position and identity. These comparisons often pit family against friends, heterosexual circles against lesbian circles, or diasporic spaces against lesbian spaces. Teresa Ruiz performs a veritable comparative study of her birthday:

Letztes Wochenende habe ich meinen Geburi gefeiert, oder? Dann habe ich so aufgeteilt, dass alle zufrieden sind: Am Freitag habe ich Hetero-Ausgang gehabt, gefeiert, am Samstag Lesben, am Sonntag Familie am Morgen. Und eben dort habe ich wirklich den Unterschied merken können. [...] Irgendwie unter Frauen [=Lesben] fühle ich mich viel wohler.

Last weekend I celebrated my birthday, you know? Then I divided it so that everyone is satisfied: On Friday I was out with the heteros, celebrated, on Saturday lesbians, on Sunday family in the morning. And well, there I could really notice the difference. [...] Somehow among women [=lesbians] I feel much more comfortable.

-Teresa Ruiz

For both Nermina Petar and Teresa Ruiz the lesbian identity and being among lesbian friends evokes the strongest sense of home and connection. Being among lesbians means being closest to oneself. Interviewees state that among lesbians, "I can be the way I am" (Nermina Petar), "I feel much more comfortable" (Teresa Ruiz), "kommt am meisten zum Ausdruck von mir, da bin ich am meisten ich" - "most of myself finds expression, it's here that I am most me" (Laura Georg).

\subsubsection{The Diasporic Community as a Site of Identification and Attachment}

By contrast, Efra Mahmoud's and Suki Schäuble's 'homing desires' are guided by nostalgia for the homeland and cultural belonging rather than by sexual identity. Theirs is the fourth way of relating to diasporic communities introduced at the outset of this subchapter. These interviewees seek to participate in their diasporic communities, with varying success. Suki Schäuble, who lives in Zürich with her husband and children while maintaining a long-distance relationship to a woman in Japan, is in close contact with many fellow Japanese in Switzerland and was also involved in introducing courses in 
the Japanese language and culture for Japanese children in Switzerland. She neither identifies as lesbian nor as bisexual, nor does she entertain any connections to the lesbian community in Switzerland or Japan. Efra Mahmoud, on the other hand, lives in Switzerland with her female partner but does not communicate her sexual orientation to the outside world. She does not frequent lesbian spaces mainly because she fears that if she were seen by the wrong people the news would travel quickly within the closeknit Egyptian community. She is also worried about being exposed as a homosexual in the Egyptian community because this is a space she very actively seeks access to. She longs to connect to someone who speaks her language, who shares her ideas of cooking and eating together, and with whom she can relive everyday Egyptian banter. However, up to the interview she das failed to forge friendships with other Egyptian women due to the lack of available candidates in her geographical vicinity.

To sum up: Queer migrant women's positionalities vis-à-vis their diasporic communities varied widely, as did the role these communities played in their everyday lives. This sub-chapter described four ways in which interviewees related to their diasporic community: Some generally refused to be relegated to diasporic (or lesbian) spaces or identities and took a decidedly anti-identitarian stance in the composition of their circles of friends. They explicitly refused to restrict their social horizons to 'ghettoized' social groups and spaces constructed on the basis of a specific sexual, national, ethnic, or cultural minoritarian identity. Others felt that they did not have much in common with other women in their diasporic community given their differing sexual orientation, biographies, lifestyles, and interests. This prevented them from creating rapport with members of these circles. Still others tended to avoid diasporic spaces because they expected, or had experienced, homophobia in these circles. They located these homophobias in their homeland cultures or in exceedingly conservative heteronormative reconfigurations of these homeland cultures in the diaspora. As pointed out before, such accounts also need to be read against the backdrop of homonationalist discourses in Switzerland, which pit allegedly homophobic 'immigrant cultures' cultures against the allegedly gay-friendly 'Swiss culture' (see Chapters 3.4.2 and 3.4.3). In order to become a 'good lesbian,' which promises the promotion of inclusion in Swiss citizenship, queer migrant women are accordingly pressed to adopt a critical stance against their homeland culture. Finally, some interviewees actively sought, but were not always successful in finding, participation in their diasporic communities. They were notably interviewees who did not identify as lesbians and did not understand their sexuality to be formative of their identities.

The ambivalence towards the diasporic community often resulted in a segregation of social worlds. Typically, one of these worlds was the diasporic community - which in the case of 'second generation' interviewees importantly contained the family of origin - where sexual deviance was mostly kept tacit. This was contrasted with a "circle of friends" among whom same-sex desires can be expressed. The composition of these circles of friends ranged from "Tout le monde!" to almost exclusively lesbian. Pitting these spaces against each other, many interviewees felt that among lesbians they can be most "the way I am." Generally, if social networks were forged along the lines of one specific minoritarian identity, they were much more often forged along the lines of sexual 
identity than the lines of national, ethnic, or cultural identity. At the same time, the sense of belonging evoked in lesbian spaces often remained troubled and incomplete. The following sub-chapter discusses this sense of lacking often expressed with regard to membership in the lesbian community, and the ways it is tied up with national, ethnic, or cultural identity on the one hand and being an immigrant in Switzerland on the other.

\subsection{Queering the Diasporic, Diasporizing the Lesbian}

Against the backdrop of a sense of unbelonging and experiences of exclusion both in diasporic and lesbian spaces, interviewees devise different strategies to create spaces in which they can simultaneously share their experiences as members of their diasporic community and as women-loving women. One of these strategies is to 'queer' diasporic spaces and vice versa to 'diasporize' lesbian spaces, that is, to create a sense of home in places that are hegemonially inscribed as either lesbian or diasporic. In such moments of attachment and identification, the hegemonic meanings attributed to diasporic or lesbian places become, at least momentarily, exposed, suspended, and challenged by the corporeal presence and visibility of the queer-and-migrant body, who is otherwise normally invisible as such.

One important site of queering the diasporic is the family. Both through in-yourface tactics as well as by more subtle or tacit methods relying on the silent agreement of Knowing that They Know, and Them Knowing that You Know They Know. These narratives of reappropriation and of (silent or not so silent) contestations with family echo the kind of dynamic home-making Anne-Marie Fortier describes below:

[Home] is lived in motions: The motions of journeying between homes, the motion of hailing ghosts from the past, the motions of leaving or staying put, of 'moving on' or 'going back,' the motions of cutting or adding, the motions of continual reprocessing of what home is/was/might have been. (Fortier 2003:130-131)

Fortier's refusal to reiterate notions of home as stasis, comfort, and security, and her suggestion to frame home in terms of movement and negotiation instead, speaks to the processes of disidentification that mark queer migrant women's negotiations with their parents. "But," Fortier continues, "home' is also remembered by attaching it, even momentarily, to a place where we strive to make home and to bodies and relationships that touch us, or have touched us, in a meaningful way" (ibid:131). For the women I interviewed, such 'sites of attachment' for homing desires were primarily places where they felt they were acknowledged as a whole, with all aspects they perceive to be relevant and defining of who they are, without having to fight for this acknowledgment. These 'aspects of the Self' are thereby not restricted to, but importantly include, their national, ethnic, or cultural identity; their cultural hybridity; their migration experience; and their dissident sexuality. Moreover, they importantly encompass issues of class, singlehood, and other aspects of life. As discussed earlier, the queer family home as a space reconciling the queer and the diasporic Self can be considered as such a site of 'intersectional home-making.' While the queer family home often represents a place 
to which homing desires are attached relatively permanently, many other instances of attaching 'homing desires' to a space remain more fleeting and volatile. One such moment - an instance in which a lesbian space becomes 'diasporized' - is presented in the following.

When Teresa Ruiz still thought of herself as a heterosexual, she mainly socialized in Spanish-Italian circles in Switzerland. After meeting her partner at work and "becoming a lesbian," she largely distanced herself from this community, instead immersing herself in the lesbian subculture. As a passionate dancer her outings focus on lesbian clubs, although here she only rarely finds dancing partners that match her proficiency. In order to increase her scope of action, she went back to her home country to learn how to lead her favorite dance (causing mystification among her male teachers: "Das ist wirklich schon ein Tabu" - "This is really a taboo"). Now, in lesbian clubs, "wenn es Latino [Musik] kommt, dann fühle ich mich schon fast wie daheim (lacht), und vor allem wirklich [wenn ich] mit Frauen tanzen kann" - "if there is Latin [music] then I almost feel at home (laughs), and above all really [when I] can dance with women." Being moved by and moving to the music of her homeland together with other women-loving women transforms the lesbian space into a queer space, merging otherwise spatially segregated aspects of herself. The social fabric of the space evokes and organizes collective memories and present shared experiences and desires, which momentarily suspends categorical identities. (Dancing to) Latin music emerges as a site of affective connection rather than an assertion of difference. For Teresa Ruiz the club momentarily becomes part of an 'urban formation' marked by shifting affiliations and interactions rather than a place from which identity claims are made and social exclusions effectuated (Kosnick 2012, Boulila 2018). In other words, in this space-time, the social practice of dancing is not determined entirely by a hegemonic discourse, which allows Teresa Ruiz to feel acknowledged in the different aspects of herself for a moment, while at the same time, albeit fleetingly, her corporeal presence and performance in this space diasporizes the otherwise hegemonially white lesbian space.

\subsection{Desiring the Queer Compatriot}

In the absence of public and semi-public places where intersecting homing desires can be attended to, queer migrant women also attach a sense of home to people. As discussed earlier, the body of the partner in the common bed represents one of the most recurring emblems of home (Chapter 6.2). Further, it is especially also the - assumed or experienced - 'equally' or 'similarly' intersectional and thus similarly exceptionally positioned 'impossible subjects' that emerge as crucial anchor points for homing desires. Real and imagined partners or friends provide such surfaces of inscription. For instance, in a telephone conversation in the context of this research, Charlotta Sembiring jokingly calculates her statistical chance of finding a partner that fits all of her criteria:

a) It has to be a woman, 'which already cuts the chance in half: 50 percent.'

b) 'Then, it has to be a lesbian: okay, five percent of 50 percent.' 
c) She has to be 'available,' which places the probability 'I don't know how many places behind the comma.'

d) She has to come from an 'academic culture.'

e) Moreover, it would ideally be an Indonesian who has been living in Europe and 'loves the European culture.' You do the math.

—Field book note of phone conversation with Charlotta Sembiring, April 4, 2008

In Charlotta Sembiring's formulation, sexual identity, educational level, national identity, cultural hybridity, and shared cultural values merge into the perfect space of comfort and mutual understanding, pointing to the intersectionality of her homing desires as they become projected onto the body of an imagined partner. (Note that the criterion that the future partner be a compatriot was a recurrent but by no means imperative desideratum in other accounts as well.)

Not only lovers but also (imagined) friends serve as surfaces of inscription for homing desires. Siti Mohd Amin, who is uncomfortable in both homonormative Swiss lesbian and heteronormative Malaysian diasporic circles, bemoans that there seems to be no other queer Malaysian women in Switzerland:

But me I don't have a group of Malaysians here. I have but in Zürich, Basel, Geneva [i.e. not in her own city], that is, auntie, uncle, you know they are old generation, so to find Malaysian like me [that is, women-loving] is very difficult that I can sharing problem together, you know?

- Siti Mohd Amin

Not even a shared (homo)sexual-and-Asian-and-diasporic identity can establish the sense of connection Siti Mohd Amin believes is required to "sharing problem together" in a meaningful way. One of her few friends in Switzerland, a young lesbian Indonesian, is 'close' to Siti Mohd Amin linguistically, culturally, sexually, and in age, but in Siti Mohd Amin's eyes these many commonalities do not 'add up' to the degree of familiarity and comfort she seeks. It is also due to this lack of people and places to which she can attach her desire to connect to a queer compatriot in Switzerland that Siti Mohd Amin resorts to the queer transnational/Malaysian online community. As discussed earlier, this ambivalent strategy at the same time mitigates and aggravates her social isolation since there is no material context in which these social ties can be enacted and developed in everyday life. While this lack of a queer-and-diasporic community is not always felt as explicitly and strongly as in the case of Siti Mohd Amin, her sense of insularity is reflected in many other accounts.

Teresa Ruiz, for instance, was incredulous when she heard that there was another Cuban lesbian in her Swiss city (see Chapter 5.1): "Ich dachte ich wäre die Einzige!" - "I thought I was the only one!" Meeting a lesbian compatriot left a lasting impression on her: "Ich glaub es ist eine von den Begegnungen, die mir da in Basel am meisten beeindruckt hat" - "I think this is one of the encounters that impressed me most here in Basel," she stated emotionally in our interview shortly after her first meeting with her queer compatriot. The two women had been on the phone together for hours since they had first met a few days before. 
A strong sense of connection among queer compatriots also finds confirmation in a little 'group' of lesbian Asians sharing the same nationality. Upon meeting in Switzerland, the three women quickly became good friends, dubbing their group "The [name of the country] Mafia." As one member of this group relates: "Y'know, when you lesbian? (laughs) [...] especially with these Asians [...], so you're trying to be, more together, eh? If you know, hey okay, we are on the same ship. All the same ship. Okay. Take the bus (laughs). Yeah." The invitation to outsiders to "take the bus" points to the strength of the 'natural' connection that the speaker perceives among queer-and-migrant compatriots, united in their multiple separation.

However, the "Mafia" never becomes a segregated and exclusive locus of a queer/national identity politics. One of the women has a European partner, and when they met for the first time all of them already had a circle of friends, so that the three have come to form the core of a large transnational, diverse, and porous circle of friends including, among others, white Swiss people, immigrants from other European countries, compatriots, other Asians, and friends from all over Europe that the three "Mafia" members know from previous stays in other European countries. In this sense this 'group' differs from the only other 'group' of queer compatriots encountered in this research, which was a circle of exclusively Spanish-speaking (but not exclusively queer) friends surrounding two Spanish research participants.

In the absence of established groups of queer compatriots, interviewees often sought to connect to other queer migrant women, believing that they will be easier to meet than Swiss lesbians because they know how it is to arrive in a foreign place as a queer person. Such expectations were often disappointed, however. When Maria Borkovic heard two women speak Serbian in a lesbian club, she was delighted: "And then I heard that they speak Serbian so it was like 'WOW! GREAT! Finally maybe I can talk with someone' you know and then I met them and they didn't ask me they didn't even make talk with me just like 'Hi, hi, whatever your name is." She was not able to forge a bond to other migrant queers in following attempts either.

To sum up: In the absence of queer communities and organizations that address migrants of a specific country, region of origin, ethnicity, or linguistic community, intersectional homing desires are attached to queer compatriots. Given the frequent absence of such compatriots in everyday life, these desires often remain confined to the realm of the imaginative, in which queer compatriots figure as ideal partners and friends. At the same time, the rare occasions on which interviewees meet queer compatriots are decisive moments that often lead to lasting friendships. ${ }^{9}$ In the absence of queer compatriots, interviewees also attempt to forge connections to queer migrants from other countries sharing their cultural background or a language, with varying degrees of success. Still others do not (actively) seek contact to compatriots, queer or not.

9 This is not to romanticize or essentialize these connections. For instance, as I write up this chapter, the "Mafia" has largely disintegrated. One of its members has returned to her country of origin while the other two have been alienated from each other. 


\section{5 "Des Suisses-Suisses on va laisser tomber":10 Being 'Other Swiss' Together}

Research participants who have come to Switzerland as adults situate themselves in between cultures. This is sometimes regarded positively in terms of a double resource ("Pour moi, je te dis j'ai deux cultures très fortes" - "For me, I tell you I have two very strong cultures" (Jimena Reyes)) and sometimes negatively in terms of a 'neither nor,' mostly resulting from an estrangement from the homeland after living in Switzerland for some time while at the same time remaining unable to forge a meaningful social network, partnership, and/or work situation in the diaspora. However, even in cases in which 'Swiss culture' is portrayed as co-constitutive of personal values and attitudes, the resulting cultural hybridity ultimately does not destabilize beliefs such as "I will never be Swiss" or that "Je suis quand même Brésilienne" - "I'm still a Brazilian after all."

As such, the 'cultural in-between-ness' formulated by interviewees who migrated to Switzerland as adults differs from the ways in which the (few) interviewees who were born in Switzerland, who were raised here from an early age, and/or who have one Swiss parent frame their cultural hybridity. ${ }^{11}$ In contrast to first generation immigrants, the latter claim Switzerland as (one of) their homeland(s). However, because they are often perceived as Ausländerinnen in Switzerland, this homeland is ultimately denied to them. In his comprehensive study of self-conceptions of people with multiple national, ethnic, and cultural belongings living in Germany, Paul Mecheril uses the term 'Other Germans' (Andere Deutsche) to designate this specific positionality (Mecheril 2003). 'Other Germans' refers to people who have grown up and live in Germany, and for whom "a transnational migration background is significant with regard to their self-conception as well as with regard to their becoming othered" (Mecheril 2003:9, my translation). They are Germans who "deviate from the fictive, prototypical image of the standard German citizen to such an extent that they are perceived as deviating too much from this image, and who are consequently perceived and treated as not legitimately belonging to the group of German citizens] [...]. The expression 'Other Germans' hence refers to a large part of the population of the children of immigrants in Germany ("Migrationsfolgegenerationen"), to 'Black Germans' [...], and to people whose parents are of diverse ethnicnational origins" (Mecheril 2003:10, my translation).

To be an 'Other German' or, in this case, an 'Other Swiss,' results in a sense of "Fremdsein in der eigenen Heimat" - "being foreign in one's own homeland" (Laura Georg). ${ }^{12}$ "Was

10 "Let's drop the Swiss-Swiss," in the sense of "Forget about making friends with Swiss-Swiss people."

11 Within the group of interviewees who came to Switzerland as children, the following analysis mainly applies to those who have one Swiss parent, which allows them to appropriate 'Switzerland' as a homeland in other ways than those whose parents are both non-Swiss.

12 Laura Ceorg's terminology resonates with discourses and cultural productions by other Europeans of color. For instance, as Fatima El-Tayeb discusses in her analysis of discourses generated by ethnic Others in postnational Europe, the 1992 song Fremd im eigenen Land (Stranger in my Country) by the band Advanced Chemistry, whose members are Germans of color, became a milestone and a source of inspiration for other young German rappers of color, many of whom understood their music as a form of political activism. Similar raps triggered similar responses in other European countries (El-Tayeb 2011:32ff). 
macht man wenn einem Heimat [in Bezug auf die Schweiz] versagt wird? Oder wenn sie einem negiert wird: Du kannst gar nicht von der Schweiz kommen so eine wie $d u$ aussiehst kannst $d u$ nicht von der Schweiz kommen. Und man kommt ja auch nicht von dort. Man hat ja verschiedene Hintergründe" - "What to do if Heimat [homeland/being at home] [in reference to Switzerland] is denied to you as such? Or if it is negated to you: You can't be from Switzerland someone like you the way you look you can't come from Switzerland. And one indeed doesn't come from there. One has different backgrounds," Laura Georg elaborates on this experience.

It is mainly this disturbing sense of "being foreign in one's own homeland" that 'Other Swiss' sought to share with others. Leyla Haddad (who has a Swiss mother and a Lebanese father and came to Switzerland from Lebanon at the age of ten) explains her desire to connect to other 'Other Swiss' as follows:

TB: Du hast gesagt du hättest so viel Freunde die so halb seien (lacht)?

LH: Also ja halb, einfach nicht Vollschweizer in dem Sinn, wobei was das immer auch heisst, jaTB: Also meinst du halb libanesisch oder grundsätzlich halb nicht schweizerisch einfach?

LH: Nein, grundsätzlich einfach, ja genau, [Leute] die irgendwie eine Mischung so entweder halbe [...], so die auch so ein bisschen Migrationshintergrund haben [...] ja wo man merkt es ist irgend wie nachher so wie ein Crundverständnis so das [...] wie Art Fremdkörper sein hier in der Kultur und vielleicht auch von-ja man ist wie ein bisschen, ja so das Lebendige das Spontane so das nicht immer Verhaltene [...], also ich habe nicht nur so Leute [im Freundeskreis], überhaupt nicht, aber ich merke es ist gleichwohl noch viel, wo ja man sucht halt sehrschnell Leute wo man ähnliche Vergangenheit hat oder eben gewisse Themen so das nicht nicht ganz hier daheim Fühlen, etwas das vermisst und gleichwohl sich versucht halt eine Identität gleichwohl halt aufzubauen und auch Ersatzfamilie [...].

TB: You said that you have a lot of friends that are like half (laughs)?

LH: Well half, just not full Swiss in this sense, whatever that means, yes-

TB: Well do you mean half Lebanese or just basically half non-Swiss?

LH: No generally, yes, exactly, [people] who are somehow a mixture like half [...], like who also have a bit of a migration background [...] yes where one realizes there is like a basic mutual understanding like [...] [about] being kind of a foreign body in this culture and maybe also because-yes one is a bit like, yes the liveliness the spontaneity like the not always guarded [...], well I don't only have people like these [in her circle of friends], not at all, but I realize it's still quite a few, where yes one very quickly looks for people who have a similar past or as I said certain issues like the not feeling completely at home here, one misses something and at the same time tries to build an identity and also a replacement family [...].

- Leyla Haddad ${ }^{13}$

Connecting to other 'Other Swiss' allows Leyla Haddad to share her experience of being a "foreign body" in Swiss culture, to build a "replacement family" even, in order to miti-

13 Leyla Haddad's wording connects to the notion of the 'halfie' by Lila Abu-Lughod, which she applies to reflect on her own positionality as a feminist ethnographer of mixed Palestinian and American parentage (Abu-Lughod 1991). 
gate her ambivalent relationship with her (Swiss) mother and the loss of her (Lebanese) father; and to tend to her desire to escape what she perceives to be an overly guarded and reserved Swiss way of interacting. Such dissociations from Swiss communication culture are echoed in other accounts (see also Chapter 9); as Ariane Velusat dryly notes about her circle of friends: "Des Suisses-Suisses on va laisser tomber" - "Let's drop the SwissSwiss," following the vein of Leyla Haddad's concept of the "Vollschweizer" (full Swiss).

While such experiences of multiple national, ethnic, or cultural belongings and the everyday strategies to navigate these belongings have been amply researched (see e.g. Mecheril 2003, Jain 2018), it has to be noted that taking a position in between different national, ethnic, or cultural belongings as well as the strategy to share cultural hybridity with similarly positioned subjects are not available to queer migrant women in the same way as they are to non-queer migrants. This surfaces in an account by Barbara Wiegand about a failed collaboration with a fellow artist sharing her father's cultural background:

Das [ein Künstlerkollege] ist mein Erzfeind, weil wir haben es mal zusammen probiert [mit arbeiten], und es ist die absolute Katastrophe gewesen, weil wir uns ohne Beaufsichtigung ins absolute Psychogebilde [ zpsychologisch sehr heikle Situation] hinein begeben haben. Und ich kann Ihnen sagen wie es geendet hat, ich bin die grosse böse Schwarze Lesbe gewesen wo dann Schuld gewesen ist, wirklich grosse böse Schwarze Frau (lacht). Und ich habe ihm per Verfügung dann eigentlich verboten das Material zu benutzen. [...] Ich hätte es hochinteressant gefunden. Weil er kommt auch aus [Heimatregion von BWs Vater] aber [seine Familie hat eine andere Herkunft], wir sind beide in der Schweiz aufgewachsen und sind knapp eine halbe Generation auseinander, also das wäre hochinteressant gewesen.

He [a fellow artist] is my nemesis, because we once tried to work together, and it was an absolute disaster, because we went into an absolute psychoconstruction [ $\approx$ psychologically very delicate situation] without supervision. And I can tell you how it ended, I was the big evil Black lesbian whose fault it was, really the big evil Black woman (laughs). And then I actually I filed a court order to prevent him from using the material. [...] I would have found it highly interesting. Because he's also from [BW's father's region of origin] but [his family has a different cultural background], we both grew up in Switzerland and are about half a generation apart from each other, so this would have been highly interesting.

-Barbara Wiegand

Again demonstrating the appeal of doing identity together with other 'similarly' positioned subjects, this account at the same time exposes once more that 'similarities' do not add up to sameness and connection. The collaboration between Barbara Wiegand and her colleague not only fails on grounds of their diverging sexual subject positions but on grounds of sexuality as intertwined with race and gender: Although Barbara Wiegand's father and her colleague's parents originate from the same region, they do not share a racial identity, which clears the way for stereotyping based on dominant images of the "Black woman" and the "Black lesbian." This story indicates that the practice of connecting to people through the assumption of shared experiences of cultural hybridity are not available to queer 'Other Swiss' in the way they may be to 'Other Swiss' who conform to sexual and gender norms. 
To conclude, interviewees who were born in Switzerland or who came to Switzerland as children often sought to connect to people who share the experience of a multiple national, ethnic, or cultural sense of belonging and in particular the experience of feeling like a foreigner in one's parents' homeland. These desires were materialized to varying degrees, yet if materialized, they sometimes failed to establish the desired sense of connection. While Leyla Haddad locates a significant number of "half" friends in her social environment, hardly any such 'Other Swiss' populate Laura Georg's social network: "Ich bin jetzt gerade selber etwas perplex" - "I'm actually a bit perplexed myself just now," she says when she realizes in the interview that her circle of friends "wirklich nichts beinhaltet mit Sri Lanka und mit anderen Ausländerinnen oder so" - "really doesn't have anything to do with Sri Lanka and with other foreigners or anything like that." However, she suspects that this eventually leads back to the very same concern about feeling foreign at home: "Ja ich denke ich bin manchmal auch schweizerischer als vielleicht eine andere Schweizerin. Ja. Weil ich das noch ein bisschen mehr brauche zur Identität"- "Yes I think I'm sometimes more Swiss than maybe the next Swiss [woman]. Yes. Because I need this a bit more for my identity."

Whether actualized or not, and whether successful or not, the very desire for sharing cultural hybridity and the troubling experience of feeling foreign in the homeland emerge as an important imaginary space throughout 'hybrid' narratives.

\subsection{Imagining and Reclaiming the (Parents') Home Country}

As Paul Mecheril emphasizes, cultural hybridity not only complicates relationships with the homeland (in this case: Switzerland) but is also productive of specific kinds of connectivities to the parents' (or one parent's) country of origin (Mecheril 2003). Maintaining the focus on the 'Other Swiss' among the interviewees, this sub-chapter engages with disidentification with and imaginations and reclamations of the parents' country of origin, specifically asking how sexuality is implicated in these connectivities.

Relationships to the parents' homeland vary widely. Natascha Schild's reflections about her connection to her homeland Kazakhstan, from which she emigrated with her family at the age of ten, is exemplary of a nostalgic inscription:

TB: Was macht es mit dir wenn du russisch oder kasachisch hörst?

NS: Ja. Es ist schon wichtig für mich, hat so ein Cewicht weil (zögert) ja es ist so ein bisschendas widerspricht sich. Weil anderseits weiss ich dass ich von der russischen oder kasachischen Cesellschaft (zögert) ich jetzt mal behaupt-nicht so akzeptiert werden würde wie jetzt hier in Europa, sagen wir mal wirklich dass ich homosexuell bin oder-ja. Das nicht, aber andererseits fehlt mir das auch also diese-diese Familien [sache?] das ist was ganz unterschiedlich oder wenn man nur zu Besuch irgendwie kommt ne? wird der Tisch aufgetischt und '] a komm! Iss mal erstmal!' Und das ist so ein anderes Umgehen na? Und die teilen das letzte Brot mit dir. Und das hört man auch ganz oft dass eh-dass die russische oder diese Kulturen das mit sich bringen diese Warmherzigkeit und die fehlt wiederum [hier]. 
TB: How do you feel when you hear Russian or Kazakh?

NS: Yes. It really is important to me, has like a weight because (hesitates) yes it's like a bit- this contradicts itself. Because on the other hand I know that I would not be accepted in the Russian or Kazakh society like that (hesitates) I would claim- that I would not be accepted [there] like here in Europe now, let's say as a homosexual oryes. Not that, but on the other hand I miss this family [thing?] this is very different if you come for a visit you know?, the table is set and 'Yes, come on! Eat first!' And this is like a different way of interaction, you know? And they will share the last piece of bread with you. And you hear this often, too, that eh- that the Russian or these cultures bring that with them this warm-heartedness and this in turn is lacking [here].

-Natascha Schild

This statement is quoted at length and with all original repetitions and breaks because they seem to signify the contradictions and struggles implied in the relationship Natascha Schild has with her parents' home country. Not in direct answer to the question the speaker first asserts her awareness that it would likely be (more) difficult to live in Kazakhstan as a homosexual (although the hesitations in this section point to the assumptive character of this perspective). From this defensive stance the speaker justifies her sustained nostalgia for the homeland. The addition "You hear this often, too...," expresses her need to corroborate her status as an expert of Kazakh society, which through this very move is called into question. Overall, Kazakhstan emerges as an important point of reference in Natascha Schild's everyday life, representing certain kinds of interactions and values she misses in Switzerland. In her everyday life Natascha Schild tends to this homesickness through her membership in a close-knit group of five Kazakh girls she had met in Germany.

Other interviewees' connectivities to the parents' home country are more ambivalent or even dystopic, such as Laura Georg's experience of her father's country of origin:

Ich habe dann-irgendwie ich muss kotzen wegen dem Essen und ich vertrage das Öl nicht und es ist mir zu heiss und ich vertrage die Armut nicht weil ich eben irgendwie auch so halb auch noch dazu, das Land will mich doch irgendwie packen aber- und das bedroht mich dann auch weil ich ich kann das- also ich kann es dann nicht (Pause) [...] Aber eben die Leila [ihre Partnerin] hat gesagt für mich sei eigentlich nicht Sri Lanka der Punkt sondern irgendetwas das dazwischen ist. [...] Es ist irgend einfach etwas nicht hier. Einfach fort. Aber dieses fort finde ich dann nirgends auf der Welt, und eben auch in Sri Lanka nicht. Und also Heimatgefühle habe ich tatsächlich keine. Oder ich lasse keine aufkommen.

Then I have to- like somehow I have to puke because of the food and the oil doesn't sit well in my stomach and it's too hot for me and I can't bear the poverty because like somehow I half [belong] to it, the country still wants to grab me somehow but- and this then also threatens me because I can't- I can't do it then (pause) [...] But as I said, Leila [her partner] said that for me Sri Lanka is not the point but something that is in between. [...] It's just something not here. Just away from here. But I don't find this 'away' anywhere in the world, and not in Sri Lanka either. And, well, indeed I don't have a sense of home [anywhere]. Or I don't let it emerge.

-Laura Georg 
Whether connected to a sense of home or a sense of rejection and unbelonging, from these two quotes the parents' country of origin emerges as a site through which home is necessarily negotiated and as such also represents a reclamation and reinscription of these places. As will be discussed next, sexuality plays a crucial role in these (dis)identifications.

In contrast to interviewees who migrated to Switzerland as adults, and in contrast to existing evidence of "roots migration" 14 of non-queer 'second generation' immigrants in Switzerland (Wessensdorf 2007), none of the interviewees addressed here are considering a more permanent 'return' to their parents' country of origin. As exemplified by Natascha Schild's statement, these reflections foreground concerns about homophobia. Since they have not lived in their parents' country of origin as adults and have never lived same-sex relationships there, interviewees have to rely on their imaginations of the lives of same-sex loving women in these places. These imaginaries are formed on the basis of media reports and family stories on the one hand and childhood memories, personal experiences, and observations from holiday visits on the other. However, since actual acquaintances with women-loving women are rare, interviewees distrust their own imagination of these realities. The resulting insecurity - mostly expressed nonverbally in interviews in the form of hesitations and a search for words - can be read as grounded in an implicit awareness of, and reluctance to adopt, Western discursive formations constructing the homeland as homophobic. Yet it is felt that parents' and families' representations of their homelands and especially their conceptualizations of, or silence about, same-sex desire in these places cannot be trusted given their different positionalities as (frequently conservative) heterosexuals.

However, interviewees also seek to be authors rather than only readers of their parents' countries of origin and strive to wrest the definition of these places from the grip of dominant heteronormative discourses. These reinscriptions can happen through the establishment of contact to queer people in these countries. Laura Georg, Leyla Haddad, Natascha Schild, and Nermina Petar all find themselves wondering what it is really like to live 'there' as a queer person and try to imagine the lives they would be leading and the kinds of persons they would be if they lived in these countries. As discussed earlier, Nermina Petar is convinced she would not be another person if she lived in Bosnia and Herzegovina: "Ich wäre auch unten lesbisch" - "I would be lesbian down there as well." Her insistence on locating her same-sex desire within herself rather than in her social context can be read as a counter discourse to her parents' view that her homosexuality is a result of over-exposure to Swiss society. It is therefore not only the troubling lacuna of information about women-loving women in Bosnia and Herzegovina that eventually motivates Nermina Petar to establish contact to queer women "down there" but also her determination to make her parents accept that there are "more of us," following the logic that proving the existence of lesbianism in 'true Bosnians' who live in Bosnia and Herzegovina would automatically disrupt the myth that there are no lesbian Bosnians. Her effort to connect to lesbian compatriots in her homeland is further driven by her sense of isolation in her struggle against the conservative heteronormative values she 
perceives to prevail in her family and generally in the Bosnian diasporic community in Switzerland. "Wie werden die [Lesben in Bosnien-Herzegowina] mit dem fertig? Familie, Kind haben, Kind nicht haben, einfach das typische Heteroleben und du bist lesbisch? [...] ich suche das Gespräch halt, zu den Landsleuten die das Gleiche erleben" - "How do they [lesbians in Bosnia and Herzegovina] cope with it? Family, having kids, not having kids, just the typical hetero life and you are lesbian? [...] I'm just looking for exchange with compatriots who experience the same." To emancipate her connections to Bosnia and Herzegovina from her family network, she uses the internet for her search. Sharing experiences over the internet proves difficult, however, as not many Bosnian women answer her queries. And while she has established regular text message conversations to one or two women in Bosnia and Herzegovina, these are complicated by language issues: Nermina Petar has lost touch with the developments of the vernacular and generally lacks vocabulary. Marked by misunderstandings, these often laborious contacts have ultimately failed to deepen.

A self-declared Bosnian "patriot," wresting the definition of what is Bosnia(n) from her parents' grip and reclaiming a Bosnian identity as a lesbian is essential for Nermina Petar. Similarly, Laura Georg is irritated with her father's quip (in the context of a discussion about Sri Lankan politics) that "You have no right to speak about Sri Lanka." She perceives her father to be acting as a gatekeeper between her family and their relatives in Sri Lanka. Laura Georg asserts that this constellation is partly of her own making, since previously she had hardly made an effort to establish independent contact to her Sri Lankan relatives. However, she has become increasingly irritated by the resistance she has encountered while attempting to intensify her relationship with an aunt she perceives to be 'different,' and possibly attracted to women. Her emerging interest in queer women's lives in Sri Lanka demonstrates her continued investment in this place despite the sense of rejection she has experienced there.

To conclude: For the 'Other Swiss' among the interviewees, the parents' home countries, while not considered as places to live in the long term, represent an important surface of inscription for homing desires. They further represent a site of negotiation of national, ethnic, and cultural identities as intertwined with sexual identities. Aspiring to act as co-authors rather than only readers of these places, interviewees reclaim the parents' home country by questioning images leavened by heteronormative discourses, and by locating women-loving women in these countries. This serves both to counteract the myth of there being no lesbians 'there' as well as to share experiences with these women-loving women. Establishing connections to these places that are located in the same country but separate from those of their parents', they seek to reconfigure their imaginations of the parental homeland on their own terms.

\subsection{Conclusion}

Queer migrant women's struggle to formulate the interstices they inhabit with respect to their sexual, national, and ethnic identities respectively testifies to the tendency of hegemonic discourses in Switzerland to separate immigrant and gay/lesbian spaces and lives. This separation is fostered both by discourses that locate homophobia in im- 
migrants' homelands and diasporic communities (which were sometimes reiterated in the accounts analyzed here) and a persistent imaginary of the homosexual as implicitly white and non-migrant. As Anne-Marie Fortier contends with respect to the difficulty queer migrant subjects experience in overcoming this separation, "the unfeasible reconciliation is largely connected to the spatial metaphors which, much like languages of immigration, suggest that the meeting of the 'two cultures' would entail moving from one into another" (Fortier 1999:2).

This conceptual and actual segregation effectuates ambiguity vis-à-vis mainstream diasporic and lesbian circles, and moreover leads to a segregation of the life-worlds that tend to these different identities separately. It also feeds the desire to be whole in one place. This desire is met by means of strategies that aim to create intersectional' queer/diasporic spaces in which crucial aspects considered to be formative of the Self are recognized in one and the same time/space. One such strategy is resistance to identify with any minoritarian space by taking an anti-identitarian stance. In such a view, exclusionary 'ghettos,' lesbian and diasporic and others, are shunned and replaced with an inclusive philosophy when establishing social relations. A further strategy is to 'queer' spaces that are hegemonially inscribed as diasporic, and vice versa 'diasporize' spaces that are hegemonially inscribed as ("Swiss-Swiss"/non-migrant) lesbian. Such queerings/diasporizations, however fleeting, allow for a momentary sense of home by a sudden visibility of the queer-and-migrant body, who is otherwise invisible as such. In the absence of designated queer/diasporic spaces, intersectional homing desires are moreover attached to the bodies of queer compatriots both in Switzerland and in one's own/the parents' homeland, or to other queer immigrants or 'Other Swiss.' However, due to a lack of eligible candidates for such partnerships or friendships, these desires often remain confined to the realm of the imaginative, especially in the case of interviewees who migrated to Switzerland as adults.

Queer migrant women's relationships to 'mainstream' diasporic circles emerge as highly ambivalent and are marked by experiences of exclusion, which are mainly related to interviewees' sexual identification and their concomitant failure to adhere to the heteronormative prescript. This indicates that the protection diasporic communities offer as bulwarks against wider racism and xenophobia is not available to queer migrant women in the same way as it is to sexually conforming women. At the same time, it was shown that the diaspora is not homophobic as such. On the one hand, as the accounts discussed here testify to, homophobia does exist in certain diasporic spaces. In this context it was argued that negative attitudes towards homosexuality must be read against the backdrop of heteropatriarchal homeland nationalisms as well as in the context of racism in Switzerland. In order to mitigate the negative effects of racism, diasporic communities work towards constructing positive images of themselves. However, these images can be shaped by masculinist nationalist ideals framing the virtuous woman as heeder of national culture, which puts diasporic women and girls under increased control and pressure. Also, in this context I again drew attention to homonationalist discourses in Switzerland. These relegate homophobia to racialized and ethnicized Others, diverting from the fact that among the 'Swiss,' too, homophobia persists, and erasing differences within the allegedly essentially homophobic 'Muslim,' 'African,' 'Balkan,' etc. societies and communities. 
On the other hand, there are also queer/diasporic linkages, more scattered, more informal, more transnational, more virtual, and more culturally and sexually hybrid, through which queer migrant women reconfigure home and a sense of connection. The existence of these queer/diasporic linkages debunks the conceptual and actual separation of diasporic and lesbian spaces effectuated through hegemonic heterosexist discourses around sexualities and cultures and allows queer migrant women to be feel more complete in one place. However, where there was no choice but to make a choice, the lesbian identity and lesbian spaces tended to be favored as the space where "I can be most the way I am." 